\title{
Effectiveness and safety of endothelial keratoplasty for pseudophakic and aphakic bullous keratopathy: a systematic review of randomized controlled trials and cohort studies
}

\author{
Eficácia da ceratoplastia endotelial no tratamento da ceratopatia \\ bolhosa pseudofácica e afácica: revisão sistemática \\ de ensaios clínicos randomizados e estudos coortes
}

Bruno Harfuch ${ }^{1}$, Amélia Kamegasawa1 ${ }^{1}$ Larissa S Harfuch², Victor Andrigheti Coronado Antunes ${ }^{3}$, Regina El Dib ${ }^{1}$

\begin{abstract}
Objective: For nearly a century, penetrating keratoplasty has been the surgical technique of choice in the management of corneal changes. However, in recent years, several lamellar keratoplasty techniques have been developed, modified or improved, especially techniques for replacing the posterior portion, for the correction of bullous keratopathy. The aim of this study was to evaluate the effectiveness and safety of endothelial keratoplasty versus penetrating keratoplasty for pseudophakic and aphakic bullous keratopathy. Methods: A systematic review of the literature was carried out, and the main electronic databases were searched. The date of the most recent search was from the inception of the electronic databases to December 11, 2015. Two authors independently selected relevant clinical trials, assessed their methodological quality and extracted data. Results: The electronic search yielded a total of 893 published papers from the electronic databases. Forty-four full-text articles were retrieved for further consideration. Of these 44 full-text articles, 33 were excluded because they were all case series studies; therefore, ten studies (with one further publication) met the inclusion criteria: one randomized clinical trial with two publications; three controlled studies; and six cohort studies. The clinical and methodological diversity found in the included studies meant that it was not possible to combine studies in a metaanalysis. Conclusions: There is no robust evidence that endothelial keratoplasty is more effective and safe than penetrating keratoplasty for improving visual acuity and decreasing corneal rejection for pseudophakic and aphakic bullous keratopathy. There is a need for further randomized controlled trials.
\end{abstract}

Keywords: Endothelial keratoplasty; keratoplasty, penetrating; Pseudophakic and aphakic bullous keratopathy

\footnotetext{
1 Faculdade de Medicina de Botucatu, Universidade Estadual Paulista "Júlio de Mesquita Filho" Botucatu, SP, Brazil.

2. Hospital Servidor Público Estadual "Francisco Morato de Oliveira", São Paulo, SP, Brazil.

${ }^{3}$ Instituto de Oftalmologia Tadeu Cvintal, São Paulo, SP, Brazil.

Study carried out at the Faculdade de Medicina de Botucatu, Universidade Estadual Paulista "Júlio de Mesquita Filho" Botucatu, SP, Brazil.

The authors declare no conflicts of interests.

Received for publication 03/02/2016 - Accepted for publication 07/03/2016
} 


\section{RESUMO}

Objetivo: Durante quase um século, a ceratoplastia penetrante tem sido a técnica cirúrgica de escolha no tratamento de doenças corneais. No entanto, nos últimos anos, têm sido desenvolvidas várias técnicas de transplante lamelar, especialmente modificadas ou aperfeiçoadas para substituir a porção posterior para a correção da ceratopatia bolhosa. O objetivo deste estudo foi avaliar a eficácia e segurança da ceratoplastia endotelial quando comparada a ceratoplastia penetrante para a ceratopatia bolhosa afácica ou pseudofácica. Métodos: Uma revisão sistemática da literatura foi realizada, e as principais bases de dados eletrônicas foram pesquisadas. A data das bases de dados da última pesquisa foi 11 de dezembro de 2015. Dois autores selecionaram independentemente os estudos relevantes, avaliaram sua qualidade metodológica e extraíram os dados. Resultados: A busca eletrônica resultou em um total de 893 artigos publicados a partir das bases de dados eletrônicas. Quarenta e quatro artigos de texto completos foram recuperados para uma análise mais aprofundada. Destes 44 artigos de texto completos, 33 foram excluídos por serem estudos de séries de casos, portanto, dez estudos (com uma publicação adicional) preencheram os critérios de inclusão: um ensaio clínico randomizado, três estudos controlados e seis estudos de corte. A diversidade clínica e metodológica encontrada nos estudos incluídos tornou impossível combinar os resultados em uma metaanálise. Conclusões: Não há evidencias robustas de que a ceratoplastia endotelial é mais eficaz e segura do que o transplante penetrante de córnea para melhorar a acuidade visual e diminuir a rejeição da córnea na ceratopatia bolhosa afácica ou pseudofácica. Há necessidade de mais estudos controlados, randomizados.

Descritores: Ceratoplastia endotelial; Ceratoplastia penetrante; Ceratoplastia endotelial com remoção da lâmina limitante posterior

\section{INTRODUCTION}

A ccording to the World Health Organization (WHO), diseases affecting the transparency of the cornea are responsible for $5.1 \%$ of the total of approximately 45 million cases of vision loss ${ }^{(1)}$. More than $50 \%$ of corneal transplants performed in the USA are performed primarily to treat endothelial dysfunction ${ }^{(2,3)}$. Brazil is the country in Latin America in which the most corneal transplants are performed. In 2011, 14,696 eyes were transplanted ${ }^{(4)}$.

In the United States of America, Fuchs' dystrophy (21.3\%) and bullous keratopathy post-cataract surgery $(12,4 \%)$ were considered the main indications for corneal transplantation, and endothelial keratoplasty is now the most common keratoplasty procedure performed there ${ }^{(2)}$.

Corneal transplantation can be divided in posterior lamellar transplantation (i.e., endothelial keratoplasty) and penetrating keratoplasty (PK). For nearly a century, penetrating keratoplasty has been the surgical technique of choice for the management of corneal modifications $(5,6)$.

Some studies have suggested greater endothelial cell loss in descemet stripping automated endothelial keratoplasty (DSAEK; $34 \%$ after six months) than in penetrating keratoplasty $(11 \%)^{(7-9)}$ while others have shown that endothelial cell loss after one year is higher with penetrating keratoplasty ${ }^{(10,11)}$. Graft survival in both techniques was similar, with better optical results with the DSAEK technique ${ }^{(11)}$.

In a Cochrane systematic review comparing endothelial keratoplasty (EK) to penetrating keratoplasty $(\mathrm{PK})$ in the treatment of Fuchs' endothelial dystrophy that included only one randomized clinical trial (RCT), the authors concluded that there was no high-quality evidence regarding the effects of EK compared to PK on visual acuity ${ }^{(12)}$.

In recent years, endothelial keratoplasty techniques have been developed and modified to improve visual results and to reduce postoperative complications due to penetrating keratoplasty.

Therefore, we evaluated the effectiveness and safety of endothelial keratoplasty compared to penetrating keratoplasty for pseudophakic and aphakic bullous keratopathy though a systematic review.

\section{Methods}

This systematic review of the literature on interventional studies was conducted in accordance with the PRISMA (Preferred Reposting Items for Systematic Reviews and Metaanalysis) statement ${ }^{(13)}$.

\section{Eligibility criteria}

We considered all randomized, controlled studies and cohort studies evaluating endothelial keratoplasty versus penetrating keratoplasty for pseudophakic and aphakic bullous keratopathy.

The outcomes assessed were visual acuity, endothelial cell count (measured by corneal specular microscopy), endothelial cell loss (as a percentage), rejection (defined as an immunological attack of the epithelium or of the endothelium for penetrating or endothelial keratoplasties, respectively), stromal endothelium, complications (e.g., increased intraocular pressure, cystoid macular edema, corneal infection) and quality of life. Studies were excluded from the review if they were duplicate publications of a study that had already been included, animal studies, case reports or review articles.

Search strategy

There was no restriction on language, year of publication or publication status. The search was performed in the following electronic databases: the Cochrane Database of Clinical Trials (CENTRAL, 2015, issue 12), PubMed (1966-2015), EMBASE (1980-2015), and LILACS (1982-2015). The databases were searched for available published and unpublished studies through December 11, 2015.

The search was conducted using multiple combinations of the following key words: endothelial and penetrating keratoplasty (Table 1).

In addition, a manual search of the bibliographic pages of the selected articles and the content pages of major ophthalmology journals was conducted. Study authors were contacted to identify additional studies.

Study selection and data extraction

The titles and abstracts were reviewed by two researchers (BF and $\mathrm{AK}$ ) to identify potentially relevant papers. The papers were obtained and independently read in full by the two reviewers. Differences were resolved by discussion and a third party (RED) 
if necessary. Reasons for exclusion were identified. The data were also extracted independently by $\mathrm{BF}$ and $\mathrm{AK}$, based on the inclusion and exclusion criteria defined above.

Risk of bias in individual studies

A risk of bias table, which is a Cochrane measurement tool used to assess the methodological quality of clinical trials, was used as a guide to conduct this systematic literature review ${ }^{(14,15)}$. We used the following six separate criteria: random sequence generation; allocation concealment; blinding; incomplete outcome data; selective reporting; and other sources of bias (e.g. conflicts of interest).

Summary measurements and synthesis of results

For dichotomous data, we used the relative risk (RR) as the effect measurement, with $95 \%$ confidence intervals (CIs). We considered a random effect model. The null hypothesis of homogeneity across individual studies was tested using the chisquare test and the $\mathrm{I}^{2}$ value.

Table 1

The search strategy that was modified accordingly for each electronic database

(keratoplasty OR (lamellar keratoplasty) OR (deep lamellar keratoplasty) OR (deep anterior lamellar keratoplasty) OR (posterior lamellar keratoplasty) OR (deep posterior lamellar keratoplasty) OR (endothelial keratoplasty) OR (endothelial lamellar keratoplasty) OR (deep lamellar endothelial keratoplasty) OR (descemet stripping endothelial keratoplasty) OR (descemet stripping automated endothelial keratoplasty) OR (descemet membrane endothelial keratoplasty) OR DSEK OR DLEK OR DMEK OR DSAEK OR (fento second laser) OR (enzymatic descemet lamellar keratoplasty) AND (penetrating keratoplasty) OR (Penetrating Keratoplasties))

\section{RESULTS}

The electronic search yielded a total of 893 published papers from the electronic databases, and this total was screened using their titles and abstracts. Forty-four full-text articles were retrieved for further consideration. Crosschecking of the references and manual searches did not yield any additional studies for inclusion. Of these 44 full-text articles, 33 were excluded because they were all case series studies; therefore, ten studies (with one further publication) met the inclusion criteria: one randomized clinical trial with two publications ${ }^{(16,17)}$; three controlled studies $(8,18,19)$; and six cohort studies ${ }^{(9-11,20-22)}$ (Figure 1).

We included 10 studies ${ }^{(8-11,16-19,21,22)}$ in this review. These studies involved a total of 21,118 participants. Coster's (20) study evaluated the most participants $(\mathrm{n}=17,065)$, while Fayez's ${ }^{(17)}$ study investigated the smallest number of patients $(n=23)$ among the studies included.

Risk of bias in the studies included See Figures 2 and 3.

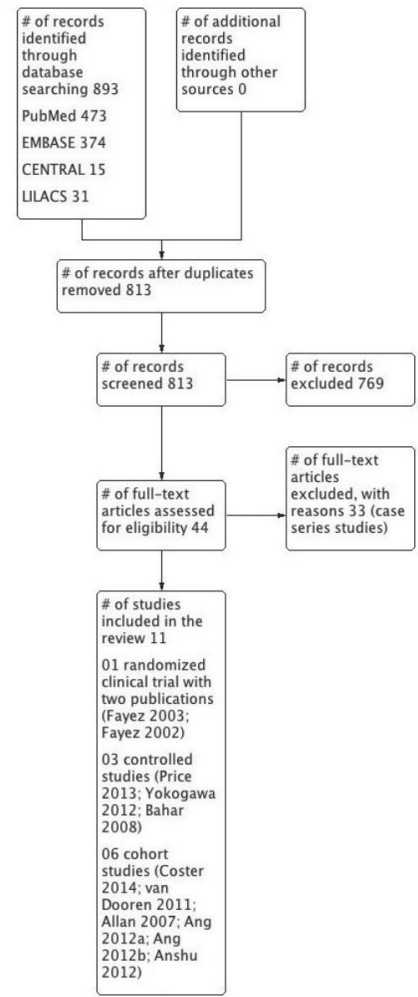

Figure 1: Flowchart of the systematic review

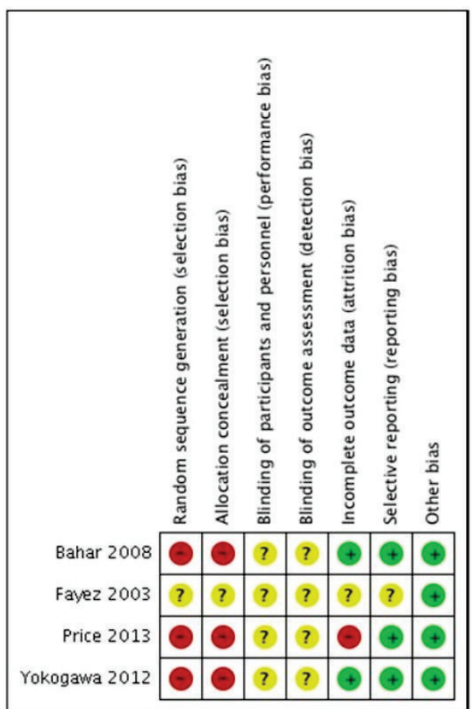

Figure 2: Risk of bias summary: review of authors' judgments about each risk of bias item for the clinical trial and controlled studies

Generation of allocation and allocation concealment

Fayez's ${ }^{(17)}$ study did not report either how the allocation was determined or the allocation concealment; thus, this study was classified as having an uncertain risk of bias for this domain. The three controlled studies ${ }^{(8,18,19)}$ were classified as having a high risk of bias because they did not perform the generation of allocation as well as the cohort studies ${ }^{(9-11,20-22)}$ and according to their design, randomization was not applicable.

Blinding

Blinding of personnel was not possible; therefore, this 
domain was ranked. The blinding of outcome assessors was only possible for visual acuity and quality of life.

None of the included studies reported on masking ${ }^{(8-11,20-}$ ${ }^{22)}$; thus, they were classified as having an uncertain risk of bias.

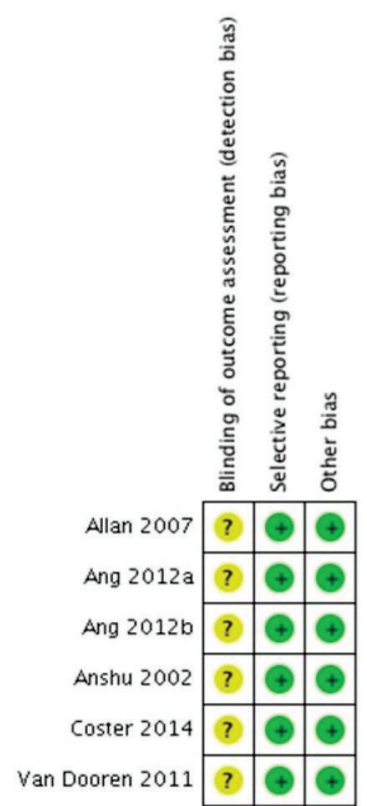

Figure 3: Risk of bias summary: review of authors' judgments about each risk of bias item for the cohort studies

\section{Incomplete outcome data}

Fayez's (17) study did not report whether there were dropouts; therefore, the study was ranked as having an unclear risk of bias. However, Price's ${ }^{(8)}$ study presented $25 \%$ withdrawals; therefore, the study was ranked as having a high risk of bias for this domain. Allan's ${ }^{\left({ }^{9}\right)}$ study reported a dropout rate of $12.5 \%$; thus, the study was classified as having a low risk of bias (less than $20 \%$ lost).

Several studies did not report whether there were losses to follow-up, and were thus ranked as having an unclear risk of bias. ${ }^{(9-11,18-22)}$

\section{Effectiveness of interventions}

The clinical and methodological diversity found in the studies included meant that it was not possible to combine studies in a meta-analysis. Furthermore, the majority of the studies did not present the data separately per clinical conditions (i.e. Fuchs' endothelial dystrophy or pseudophakic and aphakic bullous keratopathy).

\section{Discussion}

Ophthalmic surgeons worldwide have observed with enthusiasm the results of published studies showing favorable data on this new corneal transplant technique (EK) compared to penetrating keratoplasty, which is still considered a safe technique and remains the most commonly used method worldwide ${ }^{(9)}$.

Over the last two decades, new approaches to corneal decompensation resulting from endothelial diseases have been applied, including endothelial keratoplasty. In 2009, more than $40 \%$ of corneal transplants in the United States were performed using EK ${ }^{(22)}$ and the performance of this technique has been increasing in developing countries ${ }^{(23,24)}$. However, the majority of these studies presented reasonable sample sizes but short follow-up periods, and most of the studies presented selection bias classified as a high risk of bias for this domain.

Of the ten studies included, only one was a randomized, controlled trial; however, it was only available as an abstract. The remaining studies were classified as cohort or controlled studies, and they all had sample sizes of less than 769 participants ${ }^{(22)}$ except the Coster ${ }^{(20)}$ study which evaluated a very large sample of 17,065 eyes. However, we could only evaluate corrected visual acuity due to the lack of comparative tables between the EK and PK techniques.

Furthermore, the outcomes evaluated were heterogeneous among the studies included, and the surgical techniques were also different. These studies lacked blinding, thus increasing the performance and detection bias. Due to the heterogeneity of the studies, it was not possible to evaluate the included studies in a meta-analysis.

Theoretically, there is a lower risk of immune rejection due to the smaller amount of transplanted tissue and because the endothelium is located more internally, without contact with the external environment. Finally, with the EK technique, there is greater potential for the use of the corneal tissue because the front side is used for a particular patient, while the back side can be used for another patient $(25,26)$.

Despite the promising results of some studies, which increasingly encourage ophthalmologists to practice this new transplant technique, the learning curve and therefore the proficiency and cost of the procedure remain challenges to be overcome.

A recent study showed that EK is more expensive than $\mathrm{PK}$, especially if there is failure of the primary transplant and when the technique must be repeated; consequently, this increased cost might generate both patient and surgeon discomfort, and it is already known to be costly. Even when carried out by experienced surgeons who have performed more than 100 cases, cases of primary graft failure still occur ${ }^{(20)}$. Therefore, it would be prudent to enable new corneal surgeons in referral centers to improve their results and to avoid increases in hospital costs and greater suffering of patients.

More studies must be performed by experienced surgeons with adequate samples of patients. In addition, longer follow-up periods of at least five years, and other types of outcomes, such as quality of life, should also be evaluated.

There is no robust evidence that endothelial keratoplasty is more effective or safer than penetrating keratoplasty for the improvement of visual acuity and corneal endothelial cell counts, as well as decreased rejection rates in aphakic and pseudophakic bullous keratopathy.

\section{REFERENCES}

1. Resnikoff S, Pascolini D, Etya'ale D, Kocur I, Pararajasegaram R, Pokharel GP,et al. Global data on visual impairment in the year 2002. Bull. World Health Organ. 2004;82(11):844-51.

2. Eye Bank Association of America. Eye banking statistical report. Washington, DC: Eye Bank Association of America; 2013.

3. Aiken-O'Neill P, Mannis MJ. Summary of corneal transplant activity Eye Bank Association of America. Cornea. 2002;21(1):1-3.

4. Associação Brasileira de Transplante de Órgãos. Estatística de transplante. São Paulo: ABTO; 2011.

5. Kubaloglu A, Koytak A, Sari ES, Akyol S, Kurnaz E, Ozerturk Y. Corneal endothelium after deep anterior lamellar keratoplasty 
and penetrating keratoplasty for keratoconus: a four-year comparative study. Indian J Ophthalmol. 2012; 60(1):35-40.

6. Zirm E. Successful total keratoplasty. Graefes Arch Klin Exp Ophthalmol. 1906;64:581.

7. Price MO, Gorovoy M, Price Jr. FW, Benetz BA, Menegay HJ, Lass JH. Descemet's stripping automated endothelial keratoplasty outcomes compared with penetrating keratoplasty from the Cornea Donor Study. Ophthalmology. 2010;117(3):438-44.

8. Price MO, Gorovoy M, Price FW Jr, Benetz BA, Menegay HJ, Lass JH. Descemet's stripping automated endothelial keratoplasty: three-year graft and endothelial cell survival compared with penetrating keratoplasty. Ophthalmology. 2013;120(2):246-51.

9. Allan BD, Terry MA, Price FW Jr, Price MO, Griffin NB, Claesson M. Corneal transplant rejection rate and severity after endothelial keratoplasty. Cornea. 2007;26(9):1039-42.

10. Van Dooren BT, Saelens IE, Bleyen I, Mulder PG, Bartels MC, Rij GV. Endothelial cell decay after descemet's stripping automated endothelial keratoplasty and top hat penetrating keratoplasty. Invest Ophthalmol Vis Sci. 2011;52(12):9226-31.

11. Ang M, Mehta JS, Lim F, Bose S, Htoon HM, Tan D. Endothelial cell loss and graft survival after Descemet's stripping automated endothelial keratoplasty and penetrating keratoplasty. Ophthalmology. 2012;119(11):2239-44.

12. Nanavaty MA, Shortt AJ. Endothelial keratoplasty versus penetrating keratoplasty for Fuchs endothelial dystrophy. Cochrane Database Syst Rev. 2011;(7):CD008420.

13. Moher D, Liberati A, Tetzlaff J, Altman DG, The PRISMA Group. Preferred reporting items for systematic reviews and meta-analyses: the PRISMA statement. PLoS Med. 2009;6(7):e1000097.

14. Schünemann HJ, Oxman AD, Vist GE, Deeks JJ, Glasziou P, Guyatt $\mathrm{GH}$, et al. Interpreting results and drawing conclusions. In: Higgins JPT, Green S, editors. Cochrane handbook for systematic reviews of interventions version 5.0.0. The Cochrane Collaboration, 2008. [ cited 2013 Jun 11]. Available from: http://hiv.cochrane.org/sites/ hiv.cochrane.org/files/uploads/Ch12_ Interpreting.pdf.

15. Lefebvre C, Manheimer E, Glanville J. Searching for studies. In: Higgins JPT, Green S, editors. Cochrane handbook for systematic reviews of interventions version 5.0.0. The Cochrane Collaboration, 2008. [ cited 2013 Jun 11]. Available from: http:// hiv.cochrane.org/sites/hiv.cochrane.org/ files/uploads/ Ch06_Searching.pdf.

16. Al-Fayez MF. Endokeratoplasty vs penetrating keratoplasty for pseudophakic bullous keratopathy. Program and abstracts of the American Academy of Ophthalmology 2002 Annual Meeting; October 20-23, 2002; Orlando, Florida.
17. Al-Fayez MF. Endokeratoplasty vs penetrating keratoplasty for pseudophakic bullous keratopathy. Program and abstracts of the American Academy of Ophthalmology 2003 Annual Meeting; November 15-18, 2003; Anaheim, California. Poster 175.

18. Yokogawa H, Kobayashi A, Saito Y, Yamazaki N, Masaki T, Sugiyama K. Rationale for performing penetrating keratoplasty rather than DSAEK in patients with bullous keratopathy in Japan. Ophthalmic Surg. Lasers Imaging. 2012;43(6):446-51.

19. Bahar SB, Kaiserman I, McAllum P, Slomovis A, Rootman D. Comparison of posterior lamellar keratoplasty techniques to penetrating keratoplasty. Ophthalmology. 2008; 115(9):1525-33.

20. Coster DJ, Lowe MT, Keane MC, Williams KA, Australian Corneal Graft Registry Contributors. A comparison of lamellar and penetrating keratoplasty outcomes: a registry study. Ophthalmology. 2014; 121(5):979-87.

21. Ang M, Mehta JS, Anshu A, Wong HK, Htoon HM, Tan D. Endothelial cell counts after Descemet's stripping automated endothelial keratoplasty versus penetrating keratoplasty in Asian eyes. Clin. Ophthalmol. 2012;6:537-44.

22. Anshu A, Price MO, Price FW Jr. Risk of corneal transplant rejection significantly reduced with Descemet's membrane endothelial keratoplasty. Ophthalmology. 2012;119(3):536-40.

23. Bose S, Ang M, Mehta JS, Tan DT, Finkelstein E. Cost-effectiveness of Descemet's stripping endothelial keratoplasty versus penetrating keratoplasty. Ophthalmology. 2013;120(3):464-70.

24. Lichtinger A, Yeung SN, Kim P, Amiran MD, Rootman DS. The era of lamellar keratoplasty, involving surgical techniques in corneal transplantation: the University of Toronto experience. Can. J. Ophthalmol. 2012;47(3):287-90.

25. Keenan TD, Jones MN, Rushton S, Carley FM, National Health Service Blood and Transplant Ocular Tissue Advisory Group and Contributing Ophthalmologists. Trends in the indications for corneal graft surgery in the United Kingdom: 1999 through 2009. Arch Ophthalmol. 2012;130(5):621-8.

26. Terry MA, Ousley PJ. Small-incision deep lamellar endothelial keratoplasty (DLEK): six-month results in the first prospective clinical study. Cornea. 2005;24(1):59-65.

\section{Corresponding author:}

Bruno Harfuch, MD

Rua Xavantes, 36 - Xingu, Lins, SP16400-390, Brazil

Phone number: + 5514 35221457; Fax: + 551435221457

E-mail: brunoharfuch@ig.com.br 